\title{
Distribution, Status, Potentiality and Maketing Importance of Guchchi Chyau (Morchella conica, pers.) in Mugu District, Nepal
}

Ajay Karki ${ }^{1}$

\begin{abstract}
Morchella conica, pers (Guchchi Chyau) is achlorophyllus but posh fungus species often called as morel mushroom. Its use is not only limited to the household sector but also used in food and non food industries. Distribution status and potentiality is discerned in this paper and is linked it up with the financial contribution made to enhance local livelihoods. The general morphology, ecology and distribution pattern is critically analyzed to link up its importance. It is distributed within twelve VDCs of Mugu district which keeps tremendous potentiality to address the problem of poverty in the region. Information of this research based article is collected from direct field observation, focus group discussion; key informants interview and surface analysis of market structure. Haphazard and immature collections are the issues regarding its sustainability.

गुच्ची च्याउ हरितकण विहिन तर उच्च महत्व भएको ढुसी प्रजाती हो, कहिलेकाँही यसलाई मोरेल च्याउ पनि भनिन्छ। यसको प्रयोग घरयासी स्तरमा मात्र सिमित नभएर खाद्य तथा अखाद्य उद्योगहरुमा पनि गरिन्छ। यसको वितरण, अवस्था र सम्भाव्यताका साथै यसले स्थानीय जीवनयापनमा पु-याएको आर्थिक लाभका बारे यस लेखले खोजी गरेको छ। यसको महत्व दर्शाउन सामान्य रुपाकृति एवं परिवेशको चरम विश्लेषण गरिएको छ। मुगुका वाह्र गा. वि. स.मा फैलिएको यस प्रजातीले गरिवी समस्या न्यून गर्न महत्वपूर्ण भूमिका खेल्न सक्छ। अनुसन्धानमा आधारित यस लेखमा आवश्यक जानकारीहरु प्रत्यक्ष फिल्ड भ्रमण, केन्द्रित समुह छलफल, मुख्य सूचक अन्तर्वात्ता र बजार संरचनाको सतही विश्लेषण वाट गरिएको हो। जथाभावी एवं अपरिपक्व संकलन यसको दिगोपनका चुनौतीहरु हुन् ।
\end{abstract}

Key Words: Collection, Storage, Value addition, Cultivation, Marketing

\section{Introduction}

Morchella, one of the high valued commercial forest product of Nepal is found mostly in Karnali region. It is collected from national forest, community forest and also from private forest and consumed as a delicious vegetable. Collectors sell it to local traders and they airlift it to Surkhet and Nepalgunj for selling to wholesaler. Now, it has become a major income generating source for rural people.

\section{Source: Maharjan R. 2008}

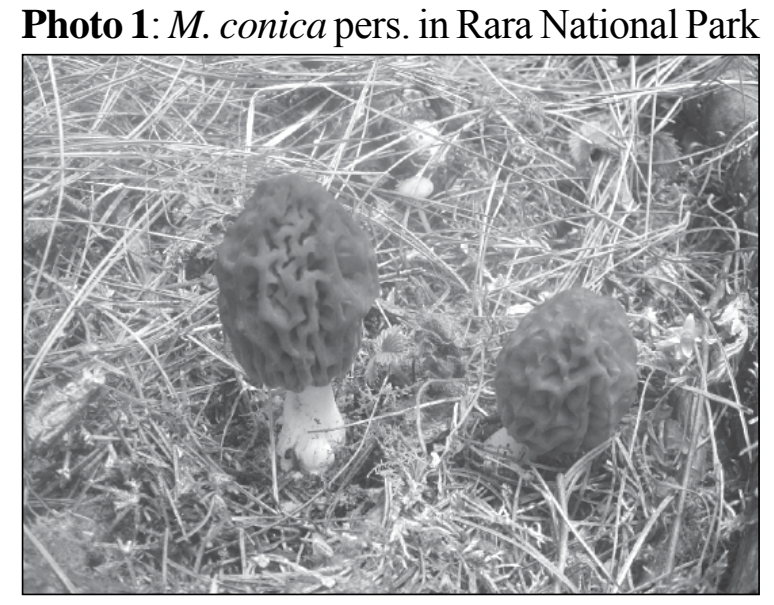

Email: clickajaya@gmail.com 
Around the world, 14 species of Morchella are found, of which 8 species are reported from Nepal (EEFA 1999). They are;

- Morchella angusticeps (Peck)

- M. conica (Pers)

- M. deliciosa $(\mathrm{Fr})$

- M. elata $(\mathrm{Fr})$

- M. esculanta (Linn) (Pers)

- M.smithiana (Cooke)

- M. vulgaris (Pers) (Boud)

- M. umbriana (Boud)

Most commonly found and traded species are M. conica and M. esculanta (Subedi, 2001).

\section{Morphology}

It is a saprophytic annual fungus with white, thick, erect and tapering stalk. Stalk bears rounded or conical pielus; having small depressions on ridges, which are asci and contain ascospores. The fruiting structure 'ascocarp' comes from the mycelium which is differentiated into conical cap shaped 'Pielus' and cylindrical stipe. Cap is light yellowish brown, $6-12 \mathrm{~cm}$ high, obtusely ovoid; pits large, ridges sinous; stipe 6-12 cm high, almost smooth, terete or faintly grooved above, sometimes pitted grooved below, minutely scurfy, yellowish browning with age and composed of compact interwoven hyphae. Fruiting body is creamy in color which is always fleshy and leathery, looks like an umbrella having small pores inside this.

\section{Ecology}

It is an achlorophyllus fungus that grows on dead and decaying woods in coniferous forests. The fruiting bodies are usually seen in clusters on organic substrata. It starts to grow in beginning of summer from March to May, rarely found growing until August. The fungus grows vigorously near and beneath the fallen trees of the previous year, where good humus has been formed. The availability and abundance in its natural habitat depends upon the rainfall and snowfall in March and April. It is reported to have short life span; visible for a maximum of 5 days from mid March onwards.

\section{Uses}

The decoction or soup is taken during or after the fever, paste is applied externally on wound. Somewhere the fruit body of morels is used to heel the cuts, ulcers and colitis. It is taken as superior nutritious soup and vegetable.

\section{Methodology}

\section{Field observation}

Coniferous forest in southern part of Seri VDC (North East of Kharka) and southern belt of Rara national park ( near Rara lake) was visited. The study time was off season of producing morels so, only the information of site was noted. 


\section{Group discussion}

Discussion with perspective stakeholders like collectors, community forest user groups, leasehold forest user group and local leaders were made to know the collection pattern, season, time investment in collection, economic contribution, processing and value addition, storage and trading pattern of species.

\section{Key informants survey}

Discussion with local traders, teachers, chair person of forest user group and collectors having age more than 50 years were made to know the market channel, legal problems and collection problems of the species.

\section{Results and discussion}

In Mugu, it is distributed from lower Temperate to sub Alpine region. Here, temperature varies from $-4^{\circ} \mathrm{C}$ in winter to $30^{\circ} \mathrm{C}$ in summer and rainfall varies from $474 \mathrm{~mm}$ to $938 \mathrm{~mm}$ per annum habitually with snowfall. It is found in large quantities in Peena, Mangri, Rowa, Seri, Rara and Pulu VDCs and found in lessser amount in Kaalai, Dhaina, Photu, Shreenagar, Rugha and Jeema VDCs.

Fig 1. Distribution of Morel mushroom in Mugu district, Nepal

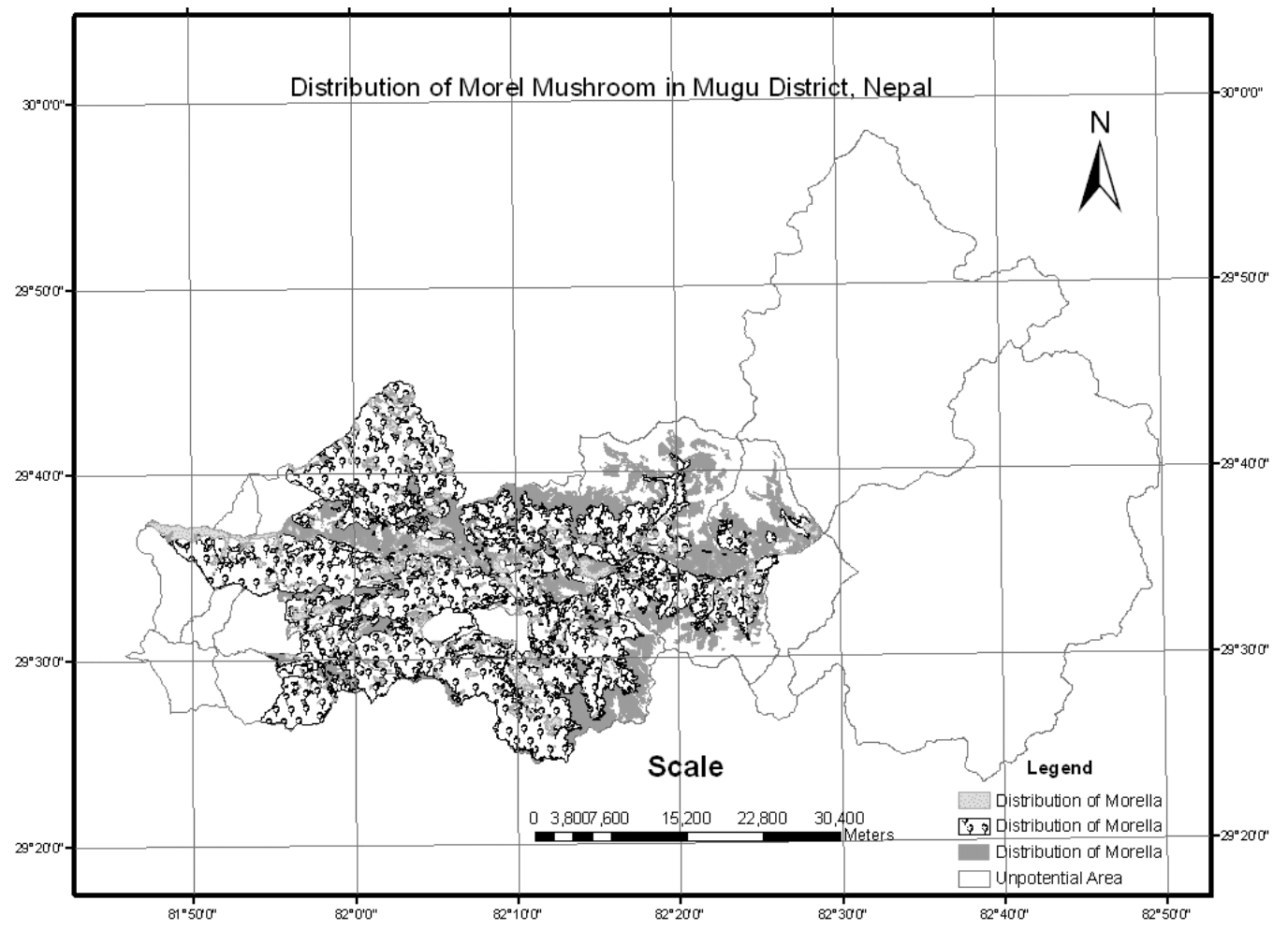

Source: NGIIP, Survey Department 
Here, it is harvested in the months of May - July. Generally, women and children collect it. Collection before maturation is major problem causing destruction in underground mycelium and soil which finally threats sustainability and production.

There is neither processing nor any kind of value additive works currently being done in Mugu, except drying, grading and packing. For storing, it should be treated immediately after collection. It is dried in sun, if there is no sun; it should be dried in open fire for 5-7 minutes. For commercial purpose, freshly collected material is sun dried and graded to avoid rejection by the buyers down at Nepaljung, Dang and Kathmandu. There is average of $40-50 \%$ weight loss in drying while the weight loss up to $90 \%$ is also reported.

Table 1: Quantity exported from Mugu district

\begin{tabular}{|c|c|}
\hline F/Y & Quantity Exported in Kg \\
\hline $057 / 058$ & 1017 \\
\hline $058 / 059$ & 566 \\
\hline $059 / 060$ & 452 \\
\hline $060 / 061$ & 1245 \\
\hline $061 / 062$ & 730 \\
\hline $064 / 065$ & 348 \\
\hline
\end{tabular}

Source: DFO Mugu, WP005/006-009/010

From this table, statistically we can conclude that Morchela is really contributing to uplift economic status. In harvesting season (May-July), women and children spend 6-8 hours everyday to collect it. They collect up to $5 \mathrm{Kg} /$ day/person.

\section{Conclusion and Recommendation}

Now an interest in non timber forest products (NTFPs) has taken the world by the storm. Vast lump of money have been invested in exploring the potential of NTFPs. Nepal is also not far from this condition. Regarding the present scenario of forestry development in Nepal; where legal exploitation of forest has been non existence or low, the importance of NTFPs has increased and emerging as primary source of revenue earning of the country. At the same time it has become one of the important item to meet the requirements of the people. Out of many NTFPs, Guchchi Chyau may become one of the potential source to uplift living standard due to its lofty demand and elevated market price up to Rs 20,000.00 per Kg.

Due to lack of research and analysis work in morel mushroom cultivation, its plantation in farmland is not yet been succeded. Immature and irrational collections is disturbing the mycelia 
during collection, endanger the plant regeneration, richness and diversity. Forest fire is detrimental to Morchella since it increases the dryness of soil and emergence of grasses (Kunwar, 2006). Collection after its complete maturation, conservation of its stands and intensive research on cultivation are imperative. Extension of its information on sustainable production and collection at collectors and farmers level may play crucial role to promote its population, richness and diversity. Dissemination of information regarding habit, habitat, collection time, maturation time, and market networking and processing of product may be the vital tool for long term production and value addition. Conservation can also be enhanced by including this species under the control of local community in operation plan of community forest and leasehold forest.

\section{Reference}

Batabaran Tatha Ban Udhyam Karyakram (EEFA) 1999. Guchi Chyau. Ban Paidawar Mala 2, BSP and New ERA, Kathmandu.

District Forest Office, Jumla, Jumla Ma Paine Gaira Kastha Ban Paidawar; Byabasthapan Ra Sambhabyata 2002.

District Forest Office, Mugu, District Forest Work Plan, 005/006 - 009/010

Hertog, W D. 1993. Non-Timber Forest Products in Dolpa District. A Report Submitted To KLDP, SNV-Nepal.

Kunwar, R. M. and Adhikari, N. 2005. Ethnomedicine of Dolpa District, Nepal: The Plants, Their Vernacular Names And Uses.

Kunwar, R. M. 2006. Non Timber Forest Product of Nepal; A Sustainable Management Approach.

Malla, S.B., Shakya, P. K., Rajbhandari, K. R., Subedi, M. N. and Shrestha, B. L. 1996. Identification Manual for Some NTFPs of Nepal. Forest Resource Information Centre Project. FINIDA and HMG Nepal.

Medicinal Plants of Nepal (Revised) 2007. Bulletin of the Department of Plant Resource.

National Population Census. 2001. Government of Nepal, National Planning Commission; Secretarial Central Bureau of Statistics

Subedi, B. P. 2001. Plant Profile: More Mushrooms. Himalayan Bioresources.

Zaidi, S. H. 2002.Conservation and Cultivation of Medicinal Plant Genetic Resources in Pakistan. In Procceding of Sharing Local And National Experience In Conservation of Medicinal and Aromatic Plants in South Asia (eds.). Bhatarai, N. and Karki, M. HMGN, IDRC and MAPPA. 